\title{
Application of Libqual Method to Measure the Optimization of Slims 8 Akasia System in the Library of Smkn Mandiri 36 Jakarta
}

\author{
Tiara Puspita Ayu \\ University of Gunadarma \\ Information Systems Management Masters \\ Program
}

\author{
Rosny Gonydjaja, PhD \\ University of Gunadarma \\ Information Systems Management Masters \\ Program
}

\begin{abstract}
The Activities of Library at SMKN Mandiri 36 Jakarta (a Vocational High School), prior to the use of library information system was still using manual system where library activities such as the registry for library visitors, borrowing and returning books were recorded in physical books. At this point, the library of SMKN Mandiri 36 Jakarta has been using the library information system, SliMS 8 Akasia, which means that library activities have applied automation in their system.. The method applied is the libqual method with 3 variables namely Quality and Access to Information (Information Control), Performance of officers in services (Affect of Services) and Library as Place, and then the data is processed through the Likert scale. The purpose of this study is to find out the quality of SLiMS library information system services to user satisfaction and to know the statements that need to be improved in order to improve the quality of SLiMS library information system services. The number of Respondents were 89 people consisted of teachers, education staff and students chose through the Slovin formula. The results from the analysis of the libquals calculation shows that the application of SLiMS service at the SMKN Mandiri 36 Jakarta library has been optimal and adequate. This can be seen from the average value for the perception of 7.97, a minimum expectation of 7.49 and an ideal expectation of 8.02 .
\end{abstract}

\section{General Terms}

Library information system, Open source system, Optimization of service

\section{Keywords}

System, SLiMS, Libqual, Library

\section{INTRODUCTION}

Before the existence of library automation, the activities in the library at the SMKN Mandiri 36 Jakarta Library was ran with a manual system where all activities were recorded in books. Such as the register for library visitors, borrowing and returning books, searching books directly through the shelves which often do not fit the subject. Unorganized arrangements of books, and no book classification numbers. Which is very inconvenient for the visitors as they do not know where to look for the books, and have to make library reports from manual records.

But nowasays, the library at SMKN Mandiri 36 Jakarta has used library automation system, which is a digital library system using the Acacia SLiMS 8 system. Book search using a book catalog, inputting data of books in SLiMS generates a barcode and a book classification number which is useful to arranged them on the shelf in order with the book's classification number.

\section{LITERATURE}

\subsection{SLiMS}

The SLiMS Library Management System (SLiMS) is a webbased Open Source Software (OSS) that covers the needs of small to large scale library automation. With features that is considerably complete and are still actively being developed, SLiMS can be used by libraries that have extensive collections, members and staff in a stand alone environments, local networks (intranets) or the internet.

\subsubsection{SLiMS Feature}

1. Online Public Access Catalog (OPAC) which creates thumbnails that are generated on the fly. Thumbnails are useful for displaying book covers. The search mode is available in simple (Simple Search) and advanced (Advanced Search) forms.

2. Detailed record (listing) XML (Extensible Markup Language) format is also available for web service needs.

3. Efficient bibliographic data management that minimizes data redundancy.

4. Masterfile management for referential data such as GMD (General Material Designation), Collection Type, Publisher, Author, Location, Supplier, and others.

5. Circulation with features: Borrow and return transactions; Collection reservation; Flexible borrowing rules; Delay and penalty information.

6. Membership management.

7. Inventory collection (stock taking).

8. Reports and Statistics Management of periodicals collection

9. Digital document support management (multimedia (.flv, .mp3, .pdf, etc.)).

10. SliMS even supports a variety of language formats including languages that do not use writing other than Latin.

11. Provides various languages of instruction (Indonesian, English, Spanish, Arabic, German, Bengali, Persian, Malay, Brazilian Portuguese, Thai, Japanese, Urdu).

12. Provides support such as Union Catalog Service Module and Nayanes as search proxy.

13. Library visitor counters. 
14. Member Area to overseen collections being borrowed by members, place borrowing orders, change user passwords, etc.

15. System modules with many features:

16. Global system configuration;

17. Module management;

18. User management (user groups and application users);

19. Off day arrangements;

20. Automatic barcode generator; Utility for backups.

\subsection{The Libqual Method}

Libqual method is the development of servqual (Service Quality) which is applied for the level of satisfaction of users on the quality of library services. The libqual (Library Quality) is one of the service guidelines used by libraries to collect, map, understand and act on the opinions of library users over the quality of the library services

(Francisca, 2013).

The variables are the Quality and Access to Information (IC Information Control), Performance of officers in the service (Affect of service) and the Library as Place.

According to Fatmnawati quoted from Rahayuningsih (2015) stated that to measure the satisfaction of user with the Libqual method is through the following formula

(Franciska, 2015).

Adequacy Gap (AG) = Perception (P) - Minimum Expectation/Hope (HM)

1. Adequacy Gap (AG), which is the value of the difference obtained from perception $(\mathrm{P})$ reduced by the minimum expectation (HM).Thus, when AG is positive, means the respondent is "quite satisfied" or is when perception> Minimum expectation ( $\mathrm{P}>\mathrm{HM})$.

2. Superiority Gap (SG) is the difference in value obtained from perception $(\mathrm{P})$ - ideal expectations $(\mathrm{HI})$.

3. When SG value is negative, means "within the tolerance limit (zone of tolerance)" is if the perception of <ideal expectations $(\mathrm{P}<\mathrm{HI})$.

Zone of Tolerance I, is an area between the minimum level of expectation (HM) that can be accepted and the ideal level of expectation (HI).

\section{RESEARCH METHODOLOGY}

This research method applied the libqual method. With descriptive analysis as the writing technique. The data were collected with questionnaires and calculations through a Likert scale. The Slovin formula was applied to determine the number of respondents.

$$
\frac{\mathrm{n}=\mathrm{N}}{1+\mathrm{Ne}^{2}}
$$

Where :

$\mathrm{n}=$ sample

$\mathrm{N}=$ Population

$\mathrm{e}=$ Estimated error rate

Retrieval errors that can still be tolerated 0.1
So the sample taken is:

$$
\begin{aligned}
& \mathrm{n}=\frac{820}{1+820(0,1)_{2}} \\
& \mathrm{n}=\frac{820}{9,2} \\
& \mathrm{n}=89
\end{aligned}
$$

Based on the sample calculated through the Solvin formula the number of respondents chosen was 89 .

\section{RESULTS AND DISCUSSION}

The data in the research was processed through the Likert scale. Likert scale is a scale used to measure the perception, attitude or opinion of a person or group on social phenomena.

Index Formula\% :

$$
\frac{\text { Total Score }}{y} \times 100
$$

\subsection{Respondent's Data Analysis}

\subsubsection{Gender}

Table 1. Gender

\begin{tabular}{|c|c|c|}
\hline Sex/Gender & Frecuency & Percentage \\
\hline Male & 57 & $64 \%$ \\
\hline Female & 32 & $36 \%$ \\
\hline Jumlah & 89 & $100 \%$ \\
\hline
\end{tabular}

As seen from the table above which shows that the respondents who more often come to the library are male with a percentage of $64 \%$ and a female with $36 \%$.

\subsubsection{Occupational Status}

Table 2. Occupational Status

\begin{tabular}{|c|c|c|}
\hline Occupation & Frecuency & Percentage \\
\hline Teacher & 15 & $16,80 \%$ \\
\hline Staff & 5 & $5,61 \%$ \\
\hline Students & 69 & $77,59 \%$ \\
\hline Total & 89 & $100 \%$ \\
& & \\
\hline
\end{tabular}


from the table above, it shows that the most of respondents were students consisted of 69 visitor with a percentage of $77.59 \%$ then followed by teachers with 15 or a percentage of $16.80 \%$ and staff as many as 5 people with a percentage of $5.61 \%$.

\subsection{Data Variable Analysis}

Table 3. Data Variable Overview

\begin{tabular}{|c|c|c|c|c|c|}
\hline Variabel & Minimum & Desired & Perceive & AG & SG \\
\hline IC 1 & 7,93 & 8,11 & 8,02 & 0,27 & $-0,09$ \\
\hline IC 2 & 7,44 & 7,83 & 7,82 & 0,38 & $-0,01$ \\
\hline IC 3 & 7,56 & 7,95 & 7,92 & 0,36 & $-0,03$ \\
\hline IC 4 & 7,44 & 7,88 & 7,77 & 0,33 & $-0,11$ \\
\hline IC 5 & 7,65 & 8,05 & 7,94 & 0,29 & $-0,11$ \\
\hline IC 6 & 7,56 & 8,11 & 8,05 & 0,49 & $-0,06$ \\
\hline IC 7 & 7,35 & 8 & 8,04 & 0,69 & 0,04 \\
\hline IC 8 & 7,22 & 8 & 7,96 & 0,74 & $-0,04$ \\
\hline IC 9 & 7,28 & 8,03 & 8 & 0,72 & $-0,03$ \\
\hline IC 10 & 7,94 & 8,23 & 8,21 & 0,27 & $-0,02$ \\
\hline IC 11 & 7,62 & 8,15 & 8,01 & 0,39 & $-0,14$ \\
\hline IC 12 & 7,49 & 8,07 & 8,02 & 0,53 & $-0,05$ \\
\hline IC 13 & 7,76 & 8,11 & 8,22 & 0,46 & 0,11 \\
\hline IC 14 & 7,77 & 8,35 & 8 & 0,23 & 0,35 \\
\hline AS 1 & 7,37 & 8,13 & 8,14 & 0,37 & 0,01 \\
\hline AS 2 & 7,55 & 8,14 & 8,29 & 0,74 & 0,15 \\
\hline AS 3 & 7,43 & 8,2 & 8,25 & 0,82 & 0,05 \\
\hline LP 19 & 7,44 & 8,25 & 8,25 & 0,81 & 0 \\
\hline LP 2 & 7,35 & 7,91 & 7,77 & 0,42 & $-0,14$ \\
\hline & & & & & \\
\hline
\end{tabular}

Explanation on the table in IC 1 shows that library visitors is able to input their own data into the library information system. With a minimum score of 7,93 , 8,11for ideal nexpectations, 8,02 for usage perceptions. Adecuacy gap (AG) score is positive 0,27 and superiority gap (SG) score is negative $-0,09$. For IC2 to LP 2 the formula calculation is then same as IC 1.

The following will explain how to calculate each dimension :

i The minimum score is 7,93 , to count the number of statements of the minimum variable is divided by the number of respondents 706: $89=7,93$.

ii Ideal expectations with a score of 8,11 , the number of statements of the ideal expectation variable is divided by the number of respondents $722: 89=$ 8,11 .

iii The perceived score is 8,02 the number of perception variable statements is divided by the number of respondents 714: $89=8,02$.

iv Adecuay gap (AG) score is positive 0,27 , the perception score - minimum expectation which is $8,02-7,93=0,27$. $\mathrm{v}$ The superiority gap (SG) score is negative -0.09 . We calculate it through the perception score - ideal expectation $8,02-8,11=-0,09$.

\subsection{Adequacy Gap (AG) Analysis}

The gap between perception and minimum expectations, is presented in the bar chart below:

\section{Grafik Bar}

\section{Adequacy Ga}

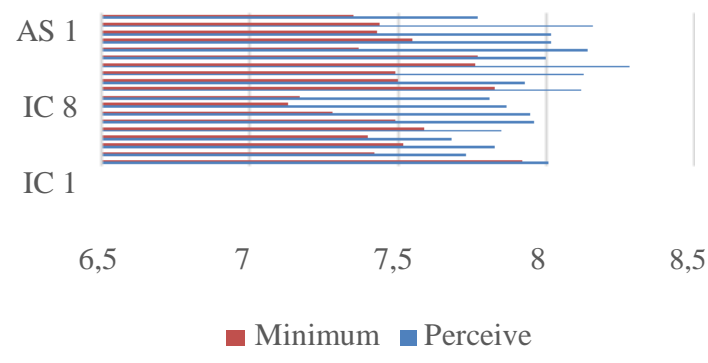

Fig 1: Adequacy Gap

From the presented bar above, it can be seen that the highest Adecuacy Bar gap is located in AS 3, AS 1, IC 13, IC 11 and IC 9 with 0.1

\subsection{Analysis of Superiority Gap (SG)}

To see the gap between perception and ideal expectations, the bar chart below can be use as a

\section{Grafik Bar}

\section{Superiority $G a$}

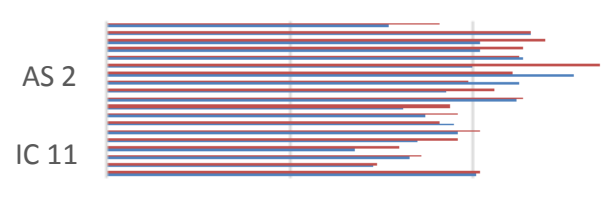

IC 6

IC 1

7 7,5 8 8,5

Disered Perceive

Fig 2: Superiority Gap

From bar diagram above, it can be seen that the biggest gap Adequacy Gap is in AS 1, IC 13 and AS 3 and the smallest is in IC 5 variable.

\section{CONCLUSION}

Based on the results of the analysis conducted, conclusions were taken as follows:

1. On how optimal is the quality and access to information (Information Control) of SLiMS services at the SMKN Mandiri 36 Jakarta Library system, the visitors rated satisfied with the SLiMS system to facilitate the search for information

2. As for the performance of officers in services (Affect of Service) in th library of SMKN Mandiri 
36 Jakarta system, visitors rated satisfied with the performance given by the staff/ officers in service. Visitors are given directions on how to use the SLiMS system and the rules in the library.

3. On the optimization of the library facility (Library as Place) in the SMKN Mandiri 36 JAKARTA Library system, visitors found quite satisfied with the library facilities and had fulfill the minimum needs of visitors therefore the library must improve library facilities in order to improve their quality.

\section{REFERENCES}

[1] Anwar, Sudirman. 2019. Manajemen Perpustakaan. Riau, Indragiri Dot Com.

[2] Dalimunthe, Nurmaini, dkk. 2016. Analisis kualitas layanan sistem informasi InlisLite menggunakan metode Libqual (Studi Kasus: Badan Perpustakaan dan Arsip Kota Pekanbaru). Jurnal Sains, Teknologi dan Industri, Vol. 13, No. 2, Juni , pp. 211-217. ISSN 1693-2390 print/ ISSN 2407 - 0939 online.

[3] Darmono. Perpustakaan Sekolah : Pendekatan Aspek Manajemen dan Tata Kerja. Grasindo. Faidah, Anna Nur, dkk.. 2016. Analisis kualitas pelayanan dengan metode Libqual (Studi pada Perpustakaan Fakultas Ekonomi dan Bisnis Universitas Lambung Mangkurat Banjarmasin. Politeknik Banjarmasin.

[4] Hendrawan, Muhammad Rosyihan. 2018. Analisis kualitas perangkat lunak Senayan Library Management
System Versi 8 Akasia sebagai Sistem. Lentera Pustaka: Jurnal Kajian Ilmu Perpustakaan, Informasi, dan Kearsipan, 4 (2) 89-100, 2018 ISSN 2302-4666.

[5] O’Brien, James A.. 2014. Sistem Informasi Manajemen. Jakarta, Salembat Empat.

[6] Marimin. Sistem Informasi Manajemen Sumber Daya Manusia. Grasindo.

[7] Nurvia, Era., dkk. 2016. Pengukuran kualitas layanan Digital Library terhadap kepuasan penggguna menggunakan metode Libqual (Studi kasus: Perpustakaan Badan Pusat Statistik Provinsi Riau).Jurnal rekayasa manajemen system informasi vol.2, No.2.

[8] Supriyanto, Wahyu. 2008. Teknologi Informasi Perpustakaan. Yogyakarta, Kanisius.

[9] Syafizal Helmi Situmorang. 2010. Analisis data: untuk riset manajemen dan bisnis. Medan, Medan USU Press.

[10] Rahayu, Franciska. 2013. Analisis Kepuasan Pemustaka Terhadap Kualtias Jasa Layanan Menggunakan Metode Libqual. Vol. 11 No. 2 ISSN: 1412-1956.

[11] Umar, Husein. 2003. Metode Bisnis: Panduan mahasiswa untuk melaksanakan riset dilengkapi dengan contoh proposal dan hasil riset bidang manajemen dan akuntansi. Jakarta, Gramedia Pustaka Utama. 